\title{
Evaluation of Methods for Determining the Consumption of Electric Power in Public Lighting Installations in Latin American Countries
}

\author{
P. Andrade ${ }^{1}$, L. Assaf ${ }^{1}$ \\ ${ }^{1}$ Departamento de Luminotecnia, Luz y Visión "Ing. Herberto C. Bühler" \\ Facultad de Ciencias Exactas y Tecnología, Universidad Nacional de Tucumán \\ Av. Independencia 1800 - 4000 (Argentina) \\ Phone/Fax number:+543814361936, e-mail: plac912@yahoo.es, lassaf@herrera.unt.edu.ar
}

\begin{abstract}
This research, part of a broader study, presents a compilation of various calculation methods used for establishing the electricity consumption in public lighting installations that lack energy meters. This situation, supposedly due to economic reasons, is common among Latin American countries. Information of public domain available in 8 countries has been compared, and as a conclusion, we can highlight the diversity of criteria used, as well as the dispersion of results obtained when applying either method, which shows that the accuracy of this electricity consumption is questionable.
\end{abstract}

\section{Key words}

Consumption, energy meter, electric power, public lighting, methods of calculation.

\section{Introduction}

Public lighting installations consume a considerable amount of electric power and though in some cases, due to the introduction of energy-efficient technology, such consumption may decrease, it can be said that it is constantly increasing. For example, in Ecuador, considering the period from 2006 to 2013, the consumption of electric power increased by $30 \%$, i.e. an average annual growth of $3.8 \%$. This amount of energy is supposed to be determined in some way. The conventional method is to segment the public lighting of a city, region or county in the various installations that compose it, measuring each one of them with an appropriate energy meter. This energy meter must be maintained, checked and read regularly, which represents an additional expense besides the installation itself. Therefore, considering that the public lighting load can be assumed as a constant, calculation methods turn out to be an economic alternative since they eliminate the expenditure of measuring, reading and maintenance installations.

The method of calculation of energy consumption comes down to solving a numerical operation based on the multiplication of the installed power by the period of functioning, considering most of them, the nominal power of the installation invariable, only dependent on inventory, and the time of connection also constant. It is worth mentioning that up to this date, as far as we know, there are no studies that compare the methods used in the countries to estimate the consumption of public lighting.

\section{Methods of calculation of public lighting electric power consumption}

A search of the expressions used to calculate energy consumption was conducted in several Latin American countries, taking into account only those cases in which the information was official and of public access. As a result, it was possible to find regulations, rules or sets of instructions of Brazil, Colombia, Ecuador, El Salvador, Guatemala, Mexico, Nicaragua and Argentina.

Before presenting the methods of calculation used in these countries, it is necessary to describe the connected power and the connection time used in these methods.

1) Full connected power. The connected power in an installation of public lighting corresponds to the addition of the power of each one of the luminaires installed and these themselves are the result of the addition of the power of each lamp plus their auxiliary equipment.

2) Connection time. The connection time of a public

lighting installation, carried out either by a command controlled by a photo-electric cell or an astronomical clock, depends on the availability of daylight in the place. Generally, daylight availability depends on latitude and the time of year. It can be estimated that at the equator, the time of daylight is the same as night's time; that is 12 hours. As we move away from the equator, and depending on the time of year, the duration of daylight increases as night time decreases in the summer, and the opposite occurs in the winter time, when nights get longer. This phenomenon, related to the Earth movement in its solar orbit, becomes more pronounced as we further 
move away from the equator. Anywhere in the world it can be said that the average length of the day or night is 12 hours, although due to the phenomenon described above, there is an imbalance between summer and winter days. Consequently, -although taken annually- we can consider 12 the number of daily hours of connection for public lighting and if it is calculated on a monthly basis, there may be an error that increases as we move away from the equator.

\section{A. Brazil [1]}

The National Agency of Electric Power (Agencia Nacional de Energía Eléctrica, ANEEL) in Normative Resolution No. 414 of September 9th, 2010, updated in 2012, considers installed power -including ancillary equipment, whose consumption is calculated based on the standards specified by the Brazilian Association of Technical Standards (Asociación Brasileña de Normas Técnicas, ABNT), manufacturer's data or tests run in laboratories accredited by the corresponding official institution- and the number of daily hours -11 hours and 52 minutes per day, except when service is required the 24 hours of a day-. Then the electric energy consumption is calculated by

$$
C E=P * t
$$

where:

$C E$ : Electric energy consumption

$P$ : installed power

$t$ : daily operating time

\section{B. Colombia [2]}

The Regulatory Commission of Energy and Gas (Comisión de Regulación de Energía y Gas, CREG), sets out in Resolution No. 123 of 2011 that consumption will be determined based on the charge resulting from the number of luminaires that are in operation, multiplied by a factor of usage expressed in hours/day and by the number of days of the billing period used for collection, applying the following formula for each voltage level n:

where:

$$
C E E_{n}=\sum_{i=1}^{3}\left(Q_{n, i} * T_{n, i} * D P F_{n}\right)
$$

$C E E_{n}$ : Consumption of electric energy in voltage level $n$ en $[\mathrm{kWh}]$

$n$ : Voltage level: $n=1$ systems with nominal voltage lower than $1[\mathrm{kV}] ; n=2$ systems with nominal voltage higher than or equal to $1[\mathrm{kV}]$ and lower than $30[\mathrm{kV}]$.

$i$ : Lighting for vehicular roads $(i=1)$, pathways for pedestrian and bicycle traffic $(i=2)$, other areas of public space $(i=3)$.

$Q_{n, i}$ : Installed load, it corresponds to the load in [kW] of the luminaires (lamps and auxiliary equipment) of the public lighting system, operated at the voltage level $n$, lighting type $i$.

$T_{n, i}$ : Hour number in the billing period of luminaires at voltage level $n$, lighting type $i$. According to the general operating conditions of lighting systems of vehicular roads and pathways for pedestrian and bicycle traffic, the hours of service provided is established between $6 \mathrm{pm}$ and 6 am. The number of hours is then equal to 12 [hours/day]. For the lighting of other public space areas under the municipality jurisdiction, whose general operating conditions are different to 12 [hours/day], the municipality may make an agreement on the corresponding number of hours/day with the company that supplies electricity. Out of the total number of operating hours of a billing period, we must deduct the number of hours in which the different kinds of lighting of the public lighting system were down for lack of electricity.

$D P F_{n}$ : Number of days from the billing period agreed between the municipality and the company that supplies electricity for the different kinds of lighting of the public lighting system installed at voltage level $n$.

\section{Ecuador [3]}

The National Counsel of Electricity (Consejo Nacional de Electricidad, CONELEC) in Regulation No. CONELEC 005/14, "Provision of General Public Public Lighting Service”, valid since September 18th 2014, sets out that consumption will be monthly determined based on the charge resulting from the number of luminaires by type, that are installed in the primary, multiplied by a factor of usage and by the number of hours of the respective month, applying the following formula:

$$
\text { Energy }=\left[T-\left(T_{f} * T_{a p}\right)\right] * \sum_{i=1}^{n}\left(P_{i}+C A_{i}\right) * N_{i} * f_{u i}
$$

where:

$i$ : Type of luminaire in the primary coil.

$P_{i}$ : Power of luminaire type $i$.

$N_{i}$ : Number of luminaires type $i$ in the primary coil.

$f_{u i}$ : It is the relation between the number of average hours that public lighting luminaires are on and the total number of hours in the analysis period (24 hours per day).

$T$ : Number of hours of the month being calculated; in the event of interruptions, at system level or primary coil, those hours will be deducted.

$T_{a p}$ : Average Time -in hours- of General Public Lighting failure assistance. Its value is calculated by dividing the summation of the real time of assistance of General Public Lighting luminaires that were reported as failing, by the number of luminaires reported as failing during the month

$T_{f}$ : System failure rate; it is calculated as the weighted average of the monthly failure rates of all primary feeder, where the weighting factor is the total number of luminaires by primary feeder divided by the total number of luminaries the company has. For quality purposes, the system failure rate cannot exceed 0.02 .

The monthly failure rate by primary feeder is calculated from the relation between the number of failing luminaires and the total number of luminaires; the total number of luminaires is the one recorded by the supplying company at the beginning of the month; whereas, the failing luminaires results from the addition of all the luminaires reported as failing during the month being calculated. The monthly record of failing luminaires is generated from the claims made by 
consumers and the monthly inspections to be performed by the supplying company to identify failing luminaires. A luminaire is considered as "failing" if: a) it is reported to be off during the time it is programmed to operate, regardless of the time spent in that state; b) if it is reported to be on during the time it is programmed to be off; and c) if it presents intermittent activity at any time of day. Should the supplying company has no information of one or more feeds, the failure rate for those feeds will be 0.04 affected by a constant, whose value depends on the number of consecutive months in which the supplying company does not have such information, as indicated below:

$$
T_{f}=0,04 *(1+x)
$$

where $x$ will be represented by the values shown in Table I.

Table I. - Constant $\mathrm{x}$ values

\begin{tabular}{|c|c|}
\hline $\begin{array}{c}\text { Consecutive months of not } \\
\text { having information }\end{array}$ & $X$ \\
\hline 2 months & 0,25 \\
\hline 3 months & 0,5 \\
\hline 4 months & 0,75 \\
\hline$>4$ months & 1 \\
\hline
\end{tabular}

$C A_{i}$ : Consumption of auxiliary equipment of luminary type i. Maximum value to be recognized as auxiliary consumption will depend on the power of the lamp installed, as shown in Table II.

Table II. - Auxiliary equipment power

\begin{tabular}{|c|c|}
\hline $\begin{array}{c}\text { Power } \\
{[\mathrm{W}]}\end{array}$ & $\begin{array}{c}\text { Maximum power in auxiliary } \\
\text { equipment } \\
{[\%]}\end{array}$ \\
\hline $\mathrm{P} \leq 70$ & 16 \\
\hline $70<\mathrm{P} \leq 100$ & 15 \\
\hline $100<\mathrm{P} \leq 150$ & 13 \\
\hline $\mathrm{P}>150$ & 12 \\
\hline
\end{tabular}

The total energy is calculated as the sum of the energy consumed by the public lighting of all primary feeders, calculated as noted above.

To determine the energy in traffic light systems, public safety and intervened public lighting -that cannot be measured due to technical causes- such energy is calculated considering the time that the required equipment needs to provide those services, also the time that they remain on, depending on the characteristics of each type of luminaire, associated equipment and its standard operation.

\section{El Salvador [4]}

The General Department of Electricity and Telecommunications Superintendence (Superintendencia General de Electricidad y Telecomunicaciones, SIGET) in its "Regulations for the Billing of Public Lighting Service" issued in 2000 and amended in Article 5, in 2012, specifies the average monthly consumption of luminaires with incandescent, fluorescent, mercury vapor, high pressure sodium and LED lamps (See Table III).
Table III. - Lamp type and power and monthly average consumption per luminary

\begin{tabular}{|c|c|c|}
\hline Type of Lamp & $\begin{array}{l}\text { Average } \\
\text { Monthly } \\
\text { Power } \\
\text { [W] }\end{array}$ & $\begin{array}{c}\text { Monthly } \\
\text { Average } \\
\text { Consumption } \\
\text { Per Luminary } \\
{[\mathrm{kWh}]}\end{array}$ \\
\hline \multirow{6}{*}{ Incandescent } & 25 & 10 \\
\hline & 40 & 16 \\
\hline & 60 & 24 \\
\hline & 100 & 40 \\
\hline & 200 & 80 \\
\hline & 300 & 120 \\
\hline \multirow{7}{*}{ Fluorescent } & 20 & 6,1 \\
\hline & 32 & 10,4 \\
\hline & 40 & 12,0 \\
\hline & 55 & 15,9 \\
\hline & 65 & 18,2 \\
\hline & $2 \times 40$ & 37 \\
\hline & $4 \times 40$ & 74 \\
\hline \multirow{3}{*}{ Mercury Vapor } & 175 & 63,4 \\
\hline & 250 & 74 \\
\hline & 400 & 125 \\
\hline \multirow{4}{*}{$\begin{array}{l}\text { High Pressure } \\
\text { Sodium }\end{array}$} & 100 & 37 \\
\hline & 175 & 55 \\
\hline & 250 & 88 \\
\hline & 400 & 134 \\
\hline \multirow{9}{*}{ LED } & 28 & 10,1 \\
\hline & 45 & 16,2 \\
\hline & 55 & 19,8 \\
\hline & 60 & 21,6 \\
\hline & 90 & 32,4 \\
\hline & 100 & 36 \\
\hline & 120 & 43,2 \\
\hline & 175 & 63 \\
\hline & 200 & 72 \\
\hline
\end{tabular}

For monthly average consumption of lamps other than the ones included above, we will use:

$$
C M=\frac{W * N H R * F P}{1000}
$$

where:

$C M$ : Monthly average consumption in [kWh] $W$ : Nominal power [W]

NHR: Number of reference hours for the operation of a lamp in a 30 day month.

It will be established that the lamp will operate continuously 12 hours a day, so:

\section{$F P$ : Power factor 0,90}

$$
\text { NHR }=12 * 30=360 \text { [hours] }
$$

1000: Conversion to [kW]

Total consumption is the sum of the product of the monthly average consumption and the number of lamps.

where:

$$
\sum_{i=1}^{n} C M_{i} L_{i}
$$

$C M_{i}$ : Monthly average consumption of lamps installed type i. 
$L_{i}$ : Number of lamps type i.

\section{E. Guatemala}

The National Commission of Electric Energy (Comisión Nacional de Energía Eléctrica, CNEE), within the period 2013-2015 issues Resolutions, where it approves that with a 12 hour daily usage, monthly consumption shall be calculated by multiplying the luminary power, factor, 12 daily hours and number of month days [5]-[19].

$$
C E=\frac{P * f * 12 * \text { days }}{1000}
$$

where:

$C E$ : Monthly energy consumption [kWh]

$P$ : Lamp power [W]

$f$ : Factor according to each supplying company between 1,017695 and 1,216405

12: Hours of daily service

días: Number of month days to determine the energy consumed (it corresponds to the previous month at billing date)

1000: Conversion to [kW]

\section{F. Mexico [20]}

The Federal Electricity Commission (Comisión Federal de Electricidad, CFE), in 2004 in its "Instructions for the interpretation and application of tariffs for electricity supply and sale," says that consumption is the result of the product between total connected load in watts, plus a factor of consumption of auxiliary equipment $1.25-25 \%$-, 12 daily hours of service and 30.4 days a month.

$$
C=P * 1,25 * 12 * 30,4
$$

where:

$C$ : Energy consumption

$P$ : Total connected load

1,25: Consumption of auxiliary equipment

12: Daily hours of service

30,4: Days of billing period

\section{G. Nicaragua [21]}

The Ministry of Energy and Mines, adopted in 2010 the "Regulations for Public Lighting", which states that the monthly energy consumed by each type of lamp reflected in the existing public lighting network inventory is calculated by multiplying the nominal load of the physical inventory of luminaries, for a period of 12 hours a day, 365 days a year, by the factor of luminaries on, which for this calculation is 0.95 and considers the $5 \%$ of luminaire failures. The resulting product is divided by the 12 months of the year, as described in the formula below:

$$
k W h / \text { month }=\frac{C N L * 12 * 365 * 0,95}{12}
$$

where:

CNL: Luminary nominal load in [kWh]

Table IV contains the values of nominal power for some luminaries with mercury and sodium lamps.
Table IV. - Lamp type and power, ballast load and luminary nominal load

\begin{tabular}{|c|c|c|c|}
\hline $\begin{array}{c}\text { Type of } \\
\text { Lamp }\end{array}$ & $\begin{array}{c}\text { Lamp } \\
\text { Power } \\
{[\mathrm{W}]}\end{array}$ & $\begin{array}{c}\text { Ballast } \\
\text { Load } \\
{[\mathrm{W}]}\end{array}$ & $\begin{array}{c}\text { Luminary Nominal } \\
\text { Load } \\
{[\mathrm{W}]}\end{array}$ \\
\hline Mercury & 100 & 17 & 117 \\
\hline Mercury & 125 & 24 & 149 \\
\hline Mercury & 175 & 4 & 179 \\
\hline Mercury & 250 & 8 & 258 \\
\hline Mercury & 400 & 19 & 419 \\
\hline Sodium & 70 & 16 & 86 \\
\hline Sodium & 100 & 23 & 123 \\
\hline Sodium & 150 & 20 & 170 \\
\hline Sodium & 250 & 25 & 275 \\
\hline Sodium & 400 & 42 & 442 \\
\hline
\end{tabular}

\section{H. Argentina [22]}

While it is true that there is no national calculation method and usually the measurement system is used instead of calculation, in the city of Rosario, Santa Fe province, according to information provided by the Directorate General of Public Lighting of the Municipality of Rosario, consumption is the result of the product of installed power -sum of luminaires power and $10 \%$ of losses due to the auxiliary equipment-, 11 hoursaverage between winter and summer- and days of operation - monthly 30 and 365 annually.

$$
C=P * 11 * d
$$

where:

$C$ : Energy consumption

$P$ : Installed power

11: Daily hours of service

$d$ : Days of monthly or annual operation

\section{Observations on the mentioned calculation methods}

The recorded methods to establish the calculation of energy consumption have their impact on the billing of public lighting service as well as on energy's rational use and they basically determine the energy consumed by each luminaire installed in the network, i.e., the power installed and operating time.

This energy is affected by two factors namely, the power of the lamps, including auxiliary equipment, and the operating time of each luminaire. Regarding the power, the accuracy of the calculation depends on the veracity and updating of the register of the luminaires. As for the time of operation, the load curve of a luminaire has only two states: on and off; for that reason, it is considered as a square wave that takes the value of the luminary's nominal power when it is on and zero when it is off. In this regard, we should mention the following considerations.

\section{A. Considerations about the power}

The power of the luminary, as indicated above, is the sum of the lamp power plus losses in the auxiliary equipment. 
In the case of Ecuador, Mexico and Argentina (Rosario) the losses in the auxiliary equipment are a percentage of the lamp power. In Nicaragua the power is set. In Brazil, Colombia, El Salvador and Guatemala the method for calculating or the value of auxiliary equipment power are not specified.

\section{B. Considerations about the time on}

The time on generally is around 12 hours a day, which per year, is represented by the values shown in Table V.

Table V. - Annual time on

\begin{tabular}{|c|l|}
\hline Country & \multicolumn{1}{|c|}{$\begin{array}{c}\text { Annual Time On } \\
{[\mathrm{h}]}\end{array}$} \\
\hline Brazil & $4.332,55$ \\
\hline Colombia & 4.380 \\
\hline Ecuador & $4.380-\left(T_{f} * T_{a p}\right)$ \\
\hline El Salvador & 4.380 \\
\hline Guatemala & 4.380 \\
\hline Mexico & $4.377,60$ \\
\hline Nicaragua & 4.380 \\
\hline Argentina (Rosario) & 4.015 \\
\hline
\end{tabular}

\section{Considerations about other factors}

A percentage for failing luminaire is allocated only in Ecuador and Nicaragua.

\section{Application of calculation methods}

When calculating the consumption of a 250[W] luminaire applying each of the methods described above, we can obtain an average consumption of 99 [kWh] with a tendency to increase or decrease 8 [kWh]. (See results in Table VI).

Table VI. - Estimate consumption and energy measurement of a 250 [W] luminary

\begin{tabular}{|l|c|c|}
\hline Country & $\begin{array}{c}\text { Estimate } \\
\text { Consumption } \\
{[\mathrm{kWh}]}\end{array}$ & $\begin{array}{c}\text { Difference of } \\
\text { consumption } \\
\text { compared to } \\
\text { Ecuador } \\
{[\%]}\end{array}$ \\
\hline Brazil & $98^{1}$ & -3 \\
\hline Colombia & 99 & -2 \\
\hline Ecuador & 101 & - \\
\hline El Salvador & 88 & -13 \\
\hline Guatemala & $106^{2}$ & 5 \\
\hline Mexico & 114 & 13 \\
\hline Nicaragua & 95 & -5 \\
\hline Argentina (Rosario) & 91 & -10 \\
\hline Average & 99 & -2 \\
\hline Deviation & $99 \pm 8$ & $-2 \pm 8$ \\
\hline
\end{tabular}

\footnotetext{
${ }^{1}$ Considering the manufacturer's data for auxiliary equipment ${ }^{2}$ Applying the formula established for the Electric Company of Guatemala Inc. (Empresa Eléctrica de Guatemala S.A.), the year 2013 presents a higher energy consumption in public lighting, according to the Statistics of the Electric Subsector issued by CEPAL.
}

\section{Conclusions}

The performed information search evidenced the existing difficulty to have access to updated official information and in some cases the lack of it.

The methods compiled show marked discrepancies among each other, both on the power value and the connection time, which leads to a standard deviation of $8 \%$ in estimated consumption. It should be noted that in some cases, arbitrary values of luminaires out of order were included, like the ones proposed by Ecuador and Nicaragua, since voltage variations, environmental conditions, defects in manufacturing, etc. affect the operation of the luminaires. Depending on the method used, different consumption can be determined by observing the highest consumption in the case of Mexico and the lowest in El Salvador due to these discrepancies for the same kind of lighting circuit. Half of the countries have consumption close to the average: Brazil, Colombia, Ecuador and Nicaragua.

These differences from one country to another could occur due to auxiliary equipment power values, operating time and failures they have.

\section{References}

[1] Agencia Nacional de Energía Eléctrica, «Resolución Normativa $N^{\circ} 414 / 2010$,» 2012. Available in: http://www.aneel.gov.br/biblioteca/downloads/livros/REN_ 414_2010_atual_REN_499_2012.pdf.

[2] Comisión de Regulación de Energía y Gas, «Resolución No. 123,» 2011. Available in:

http://apolo.creg.gov.co/Publicac.nsf/1c09d18d2d5ffb5b052 56eee00709c02/c2081b22df5fd51e0525791e007d7ba9?Ope nDocument\&Highlight=0,NoResolucionCREG123-2011.

[3] Consejo Nacional de Electricidad, «Regulación No. CONELEC 005/14 Prestación del Servicio de Alumbrado Público General 2014,» 2014. Available in: http://www.conelec.gob.ec/normativa/Regulaci\%C3\%B3n \%20No.\%20CONELEC\%20005_14\%20Prestaci\%C3\%B3n \%20APG.pdf

[4] Superintendencia General de Electricidad y Telecomunicaciones, «Normativa para la Facturación del Servicio de Alumbrado Público,» 2012. Available in: http://www.siget.gob.sv/attachments/1905_Public.\%20Acue rdo\%20936-E-2012\%20SIPP-0026-2013.pdf.

[5] Comisión Nacional de Energía Eléctrica, «Resolución CNEE-194-2013,» 2013. [En línea]. Available in: http://www.cnee.gob.gt/pdf/resoluciones/2013/CNEE\%201 94\%202013.pdf.

[6] Comisión Nacional de Energía Eléctrica, «Resolución CNEE-218-2013,» 2013. Available in: http://www.cnee.gob.gt/pdf/resoluciones/2013/CNEE\%202 18\%202013.pdf.

[7] Comisión Nacional de Energía Eléctrica, «Resolución CNEE 029-2014,» 2014. Available in: http://www.cnee.gob.gt/pdf/resoluciones/2014/CNEE\%200 29\%202014.pdf.

[8] Comisión Nacional de Energía Eléctrica, «Resolución CNEE-062-2014,» 2014. Available in: http://www.cnee.gob.gt/pdf/resoluciones/2014/CNEE\%200 62\%202014.pdf.

[9] Comisión Nacional de Energía Eléctrica, «Resolución CNEE-063-2014,» 2014. Available in: 
http://www.cnee.gob.gt/pdf/resoluciones/2014/CNEE\%2006 3\%202014.pdf.

[10] Comisión Nacional de Energía Eléctrica, «Resolución CNEE-220-2014,» 2014. Available in: http://www.cnee.gob.gt/pdf/resoluciones/2014/CNEE\%2022 0\%202014.pdf.

[11] Comisión Nacional de Energía Eléctrica, «Resolución CNEE-124-2015,» 2015. Available in: http://www.cnee.gob.gt/pdf/resoluciones/2015/CNEE\%2012 4\%202015.pdf.

[12] Comisión Nacional de Energía Eléctrica, «Resolución CNEE-125-2015,» 2015. Available in: http://www.cnee.gob.gt/pdf/resoluciones/2015/CNEE\%2012 5\%202015.pdf.

[13] Comisión Nacional de Energía Eléctrica, «Resolución CNEE-126-2015,» 2015. Available in: http://www.cnee.gob.gt/pdf/resoluciones/2015/CNEE\%2012 6\%202015.pdf.

[14] Comisión Nacional de Energía Eléctrica, «Resolución CNEE-127-2015,» 2015. Available in: http://www.cnee.gob.gt/pdf/resoluciones/2015/CNEE\%2012 7\%202015.pdf.

[15] Comisión Nacional de Energía Eléctrica, «Resolución CNEE-128-2015,» 2015. Available in: http://www.cnee.gob.gt/pdf/resoluciones/2015/CNEE\%2012 8\%202015.pdf.

[16] Comisión Nacional de Energía Eléctrica, «Resolución CNEE-129-2015,» 2015. Disponible en: http://www.cnee.gob.gt/pdf/resoluciones/2015/CNEE\%2012 9\%202015.pdf.

[17] Comisión Nacional de Energía Eléctrica, «Resolución CNEE-130-2015,» 2015. Available in: http://www.cnee.gob.gt/pdf/resoluciones/2015/CNEE\%2013 0\%202015.pdf.

[18] Comisión Nacional de Energía Eléctrica, «Resolución CNEE-131-2015,» 2015. Available in: http://www.cnee.gob.gt/pdf/resoluciones/2015/CNEE\%2013 1\%202015.pdf.

[19] Comisión Nacional de Energía Eléctrica, «Resolución CNEE-132-2015,» 2015. Available in: http://www.cnee.gob.gt/pdf/resoluciones/2015/CNEE\%2013 2\%202015.pdf.

[20] Comisión Federal de Electricidad, «Instructivo para la Interpretación y Aplicación de las Tarifas para el Suministro y Venta de Energía Eléctrica,» 2004. Available in: http://www.delrealenergy.com/documentacion/Instructivo_In terpretacion de tarifas NOV04.pdf.

[21] Ministerio de Energía y Minas, «Normativa de Alumbrado Público,» 2010. Available in: http://www.ine.gob.ni./DGE/normativas/Normat Alumb Pub lico.pdf.

[22] Dirección General de Alumbrado Público de la Municipalidad de Rosario, 2014. 